\title{
Antioxidant Status in Normal Pregnancy and Preeclampsia upon Multivitamin-Mineral Supplementation in the Region of Vojvodina
}

\author{
Tatjana N. Ćebović, Daniela Marić, Aleksandra Nikolić, and Aleksandra Novakov-Mikić
}

\begin{abstract}
Normal pregnancy is associated with oxidative stress and this is even increased during preeclampsia $(\mathrm{PE})$. The decrease in total antioxidant capacity is the pathophysiological basis for vitamin supplementation during pregnancy, but the beneficial effect of this approach is still unclear. Levels of creatinine, urea, cystatin, malondialdehyde (MDA), superoxide dysmutase activity (SOD), glutathione peroxidase (GSH-Px) activity and acidum ascorbicum were measured in the serums of all women. Mean MDA level in maternal plasma in normal pregnancies was significantly lower than in $\mathrm{PE}$ pregnancies $(2,78 \pm 0.78 \mathrm{pmol} / \mathrm{mg}$ vs $3.20 \pm 0.91 \mathrm{pmol} / \mathrm{mg}, \mathrm{p}<0.05)$, as well as mean GSH-Px levels $(811 \pm 206 \mathrm{U} / \mathrm{l}$ vs $1350 \pm 575 \mathrm{U} / \mathrm{l}, \mathrm{p}<0.05$. Mean ascorbic acid values were significantly higher in normal than in PE pregnancies $(9,85 \pm 2,43 \mathrm{mg} / \mathrm{L}$ vs $5.54 \pm 1.81 \mathrm{mg} / \mathrm{L}$, $\mathrm{p}<$ $0.001)$, as well as mean SOD values $(26.8 \pm 18.45 \%$ vs $12.3 \pm 10.3 \%, p<0.001)$. There were no significant differences in normal pregnancy group with and without multivitamin supplementation. MDA levels were significantly lower in PE pregnancies with vitamin supplementation $(2.99 \pm 0.81 \mathrm{pmol} / \mathrm{mg}$ vs $3.42 \pm \mathbf{1 . 0 1} \mathrm{pmol} / \mathrm{mg}$, $\mathbf{p}<\mathbf{0 . 0 5})$, as well as GSC-Px levels (1200 $\pm 500 \mathrm{U} / 1$ vs $1500 \pm 650 \mathrm{U} / 1, \mathrm{p}<\mathbf{0 . 0 5})$. Ascorbic acid values were significantly higher in the $P E$ group with vitamin supplementation $(6.16 \pm 1.66 \mathrm{mg} / \mathrm{L}$ vs $4.92 \pm 1.96 \mathrm{mg} / \mathrm{L}$, $\mathbf{p}<0.05)$, as well as SOD levels $(13 \pm 11.4 \%$ vs $11.6 \pm 9.2 \%, p<0.001)$.
\end{abstract}

Index Terms-Preeclampsia, oxidative stress, vitamins, superoxide dismutase, creatinine, cystatine.

\section{INTRODUCTION}

Human pregnancy imposes a huge stress to the maternal body which has to accommodate the increasing energy needs of the developing fetus at the expense of its own needs. Therefore, several physiologic and metabolic changes take place in the maternal body to adapt to such a challenge. The pregnant uterus undergoes important tissue and vascular remodeling, the most remarkable of which is the

Manuscript received October 30, 2012; revised January 10, 2013. This work was supported in part by the Vojvodina Government under Grant 114-451-2661/2012-02

T. N. Ćebović is with the Biochemistry Department, Faculty of Medicine Novi Sad, University of Novi Sad, Clinical Centre of Vojvodina, Novi Sad, Vojvodina, Serbia (e-mail: cebovictatjana@gmail.com).

D. Marić is with the Department of Infectious Diseases, Faculty of Medicine, University of Novi Sad, Clinical Centre of Vojvodina, Novi Sad, Vojvodina, Serbia (e-mail: dijetinfo@gmail.com).

A. Nikolić is with the Department of Laboratory Diagnostics, Clinical Centre of Vojvodina, Novi Sad, Vojvodina, Serbia (e-mail: sanjaigaga@neobee.net).

A. Novakov-Mikić is with the Department of Obstetrics and Gynaecology, Faculty of Medicine, University of Novi Sad, Clinical Centre of Vojvodina, Novi Sad, Vojvodina, Serbia (e-mail: aleksandranovakov@gmail.com). transformation of the uterine spiral arteries into low-resistance flow vessels that enable large volumes of blood to gain access to the placental intervillous space [1].

Due to metabolic changes and low grade inflammation, pregnancy is a condition of increased susceptibility to oxidative stress [1], [2]. Several organs in pregnancy show increased basal oxygen consumption and changes in substrate energy use resulting in increased mitochondrial mass and production of reactive oxygen species (ROS) [3]. The placenta is another local source of free radicals. It produces nitric oxide (NO), but also, because it's so rich with free radical producing macrophages, it can contribute to the development of oxidative stress [4], [5].

Preeclampsia (PE) is a serious complication of the second half of human pregnancy, which can have harmful effects on the immediate and long-term health of the mother and the child [6]. This disease is characterized by multiple maternal disturbances leading to hypertension and proteinuria [7]. The symptoms resolve only after the removal of the placenta, and thus, $\mathrm{PE}$ is one of the most common reasons for induced preterm delivery. Although the cause of PE remains largely unknown, the occurrence of oxidative stress is a feature of the maternal syndrome. The main source of ROS initiating the pathophysiological events appears to be the placenta [8] Abnormal vascular development of the blood vessels in the preeclamptic placenta leads to reduced placental perfusion and to induce hypoxia which is by itself a potent stimulus for ROS formation [9]. Also, after initiation of apoptotic pathways, syncytiotrophoblast microvesicles activate maternal neutrophils contributing to oxidative stress and pathophysiology of PE. It has been observed that ROS are increased, and the levels of several detoxifying enzymes are reduced in PE. One of the most important lipid peroxidation products is malondialdehyde (MDA) which serves as a potential biomarker of oxidative damage and disease severity [10]. In preeclamptic women, it was found that MDA levels correlate with the severity of the disease and are a good indicator of lipid peroxidation and oxidative stress levels. [8], [11], [12].

Several antioxidant enzymes have been studied in normal and preeclamptic pregnancies. In normal pregnancy, by 10 to 12 weeks of gestation, the onset of maternal blood flow in the placenta results in a local increase in oxygen tension and parallel elevation in the expression and activity of the antioxidant enzymes [13]. On the contrary, the increased concentration of superoxide in the placental tissue of preeclamptic women was found associated with decreased activity and plasma levels of SOD mRNA expression [14], 
[15]. Levels of gluthatione peroxidase were also found to be decreased in PE and could be associated with increased generation of toxic lipid peroxides contributing to the endothelial dysfunction and hypertension of PE [16], [17].

Plasma levels of the reduced form of ascorbic acid, a water-soluble vitamin, were reported to be significantly decreased in patients with both mild and severe PE. The reason for the decreased plasma ascorbate is not clear but is consistent with the hypothesis that uteroplacental perfusion induces oxidative stress and ascorbate consumption [18].

Antioxidant supplementation in normal and preeclamptic pregnancies is recommended in our country on the basis of the overproduction of ROS and decreased antioxidant defense systems. We evaluated the effect of a multivitamin-mineral preparation in the maternal oxidative stress in a group of women with uncomplicated and PE complicated pregnancy.

\section{MATERIALS AND METHODS}

A. Population

TABLE I: COMPOSITION OF MULTIVITAMIN-MinERAL SUPPLEMENT

\begin{tabular}{ll}
\hline \hline Micronutrient & dosage \\
\hline Vitamin D & $5 \mu \mathrm{g}$ \\
Vitamin E & $15,0 \mathrm{mg}$ \\
Vitamin B1 & $3,0 \mathrm{mg}$ \\
Vitamin B2 & $3,4 \mathrm{mg}$ \\
Vitamin B6 & $3.0 \mathrm{mg}$ \\
Niacin & $17.0 \mathrm{mg}$ \\
Folic acid & $400 \mu \mathrm{g}$ \\
Pantothenic & $10.0 \mathrm{mg}$ \\
Biotin & $30 \mu \mathrm{g}$ \\
Vitamin B12 & $3 \mu \mathrm{g}$ \\
Beta-carotene & $720 \mu \mathrm{g}$ \\
Vitamin C & $100 \mathrm{mg}$ \\
Calcium & $250 \mathrm{mg}$ \\
Magnesium & $52.5 \mathrm{mg}$ \\
Zinc & $10 \mathrm{mg}$ \\
Copper & $1.0 \mathrm{mg}$ \\
Iodine & $130 \mu \mathrm{g}$ \\
Iron & $14 \mathrm{mg}$ \\
Manganese & $2,0 \mathrm{mg}$ \\
Selenium & $25 \mu \mathrm{g}$ \\
Chrome & $25 \mu \mathrm{g}$ \\
Molybdenum & $25 \mu \mathrm{g}$ \\
\hline \hline
\end{tabular}

The study was conducted at the Clinic for Gynaecology and Obstetrics, Clinical Centre of Vojvodina (Serbia), and it was approved by the Ethics Committee. We included 3 groups of pregnant women: 34 uncomplicated pregnant women taking multivitamin-mineral supplement, 30 preeclamptic women taking the same supplement and 30 uncomplicated pregnant women not taking the same supplement. The supplement was a standard, OTC multivitamin-mineral preparation (commercial name and manufacturer are known to researchers). Its composition is described in Table I. The
Suplement was prescribed upon decision of the woman's gynecologist. All women gave written informed consent in order to participate in the study. Women were matched for gestational age at entry.

We collected data on maternal age, gestational age at entry, gravidity, parity, smoking habits and BMI.

Venous blood samples were taken from women on admission. Plasma and serum were stored at $-80^{\circ} \mathrm{C}$.

\section{B. Laboratory}

Level of malonyldialdehyde (MDA) was measured using OxiSelect MDA Adduct ELISA kit, following the manufacturer revised protocol. BSA standards or protein samples $(10 \mu \mathrm{g} / \mathrm{mL})$ were adsorbed onto a 96-well plate for 2 hours at $37^{\circ} \mathrm{C}$. The MDA-protein adducts present in the sample or standard were probed with an anti-MDA antibody, followed by an HRP conjugated secondary antibody. The MDA protein adducts content in an unknown sample was determined by comparing with a standard curve that was prepared from predetermined MDA-BSA standards. Sensitivity of the method varies from $1.875 \mathrm{pmol} / \mathrm{mg}$ to 120 $\mathrm{pmol} / \mathrm{mg}$ MDA Adduct.

Superoxide dismutase activity (SOD) was determined using OxiSelect ${ }^{\mathrm{TM}}$ Superoxide Dismutase Activity Assay, following the manufacturer revised protocol. Superoxide anions $\left(\mathrm{O}_{2}{ }^{-}\right)$are generated by a Xanthine/Xanthine Oxidase (XOD) system, and then detected with a Chromagen Solution. In the presence of SOD, superoxide anion concentration is reduced, yielding decreased colorimetric signal. We used the activity assay standard curve to measure the activity of the enzyme.

Glutathione peroxidase activity (GSH-Px) was determined using Ransel ${ }^{\mathrm{TM}}$ Glutathione Peroxidase Activity Assay produced by RANDOX. We used the manufacturer protocol that follows the original method developed by Paglia and Valentine [19]. The method is based on the reaction below:

$$
\begin{aligned}
& 2 \mathrm{GSH}+\mathrm{ROOH} \rightarrow \mathrm{GSSG}+\mathrm{ROH}+\mathrm{H}_{2} \mathrm{O} \text { (glutathione } \\
& \text { peroxidase) } \\
& \begin{array}{l}
\mathrm{GSSG}+\mathrm{NADPH} \\
\text { reductase })
\end{array}
\end{aligned}
$$

$(\mathrm{ROOH}=$ cumene hydroperoxide; $\mathrm{GSH}=$ reduced glutathione; GSSG = oxidised glutathione)

The GSH-Px activity (level) is assessed from the decrease in absorbance at $340 \mathrm{~nm}$ due to the oxidation of NADPH to $\mathrm{NADP}^{+}$.

Ascorbic acid was determined using the colorimetric microtiter assay kit supplied by Immundiagnostik AG (Bensheim, Germany). In brief, serum and plasma vitamin $\mathrm{C}$ was detected as ascorbic acid as well as its oxidized form, dehydroascorbate. A dose response curve of the absorbance at $492 \mathrm{~nm}$ vs. concentration is generated, using the values obtained from the standard. The concentration of the patient sample is determined directly from the linear standard curve. Preparation of all working reagents, standards, and experimental procedure were strictly conducted according to the procedures recommended by manufacturer. Normal range was $4-15 \mathrm{mg} / \mathrm{L}[20]$. 
Serum cystatin C level was measured by automated latex enhanced immunoturbidimetric assay, using commercial Diazyme kits (Poway, USA) with intra- and interassay \% CV less than $5 \%$, and according to the procedure recommended by reagent manufacturer.

Serum creatinine levels were measured by kinetic colour test (Jaffe method), using commercial Beckman Coulter kits (Galway, Ireland) with intra- and interassay \%CV less than $2.45 \%$, and according to the procedure recommended by reagent manufacturer.

Serum uric acid levels were measured by standardized enzymatic PAP method with uricase and peroxidase, using commercial Beckman Coulter kits (Galway, Ireland) with intra- and interassay \% CV less than $2.44 \%$, and according to the procedure recommended by reagent manufacturer.

In patients with $\mathrm{PE}$ urin, we also measured total protein levels using a modified dye binding method of Fujita et al. [21], using commercial Siemens kits (Siemens Health Care Diagnostics, Inc., Tarrytown, NY, USA ).

\section{Statistical ANALYSIS}

We presented continuous data as means \pm Standard deviations (SDs) or median and range as appropriate. We compared groups using 1-way ANOVA or 2-tailed Student $t$ test/Mann-Whitney $U$-tests depending on the distribution. Correlations between the parameters were tested with either Pearson or Spearman Ranks correlation tests. The null hypothesis was rejected where $p<0.05$. We used SPSS version 14.0 to perform the statistical analyses.

\section{RESULTS}

We included a total of 94 pregnant women. Table II describes the demographic and obstetric characteristics of the participants.

The PE group had significantly higher gravidity and BMI, but the groups were similar in age, parity, gestation week at the time of admission and percentage of smokers (Table II).

The maximum systolic blood pressure in the PE group was 220 (median 165, SD 19.9), and maximum diastolic blood pressure was 140 (median 105, SD 10.8). Proteinuria in this group was maximum $13.9 \mathrm{~g}$ (median $3.1 \mathrm{~g}$, SD $3.8 \mathrm{~g}$ ).

TABLE II: DEMOGRAPHIC AND PREGNANCY DATA OF SUBJECT GROUPS

\begin{tabular}{|c|c|c|c|c|}
\hline & $\begin{array}{l}\text { Normal } \\
\text { pregnancy } \\
\text { using } \\
\text { supplement } \\
(\mathrm{n}=34)\end{array}$ & $\begin{array}{l}\text { Normal } \\
\text { pregnancy } \\
\text { no } \\
\text { supplement } \\
(\mathrm{n}=30)\end{array}$ & $\begin{array}{l}\text { PE using } \\
\text { supplemen } \\
\mathrm{t}(\mathrm{n}=30)\end{array}$ & $\begin{array}{l}P \\
\text { value }\end{array}$ \\
\hline Maternal age, yrs & $30.6 \pm 4.29 *$ & $29.15 \pm 4.74$ & $30.2 \pm 5.8$ & 0.475 \\
\hline Gestation week & $31.20 \pm 4.89$ & $31.53 \pm 3.17$ & $31.5 \pm 3.2$ & 0.891 \\
\hline Maternal gravidity & $0.65 \pm 0.85$ & $0.77 \pm 1.19$ & $1.43 \pm 1.16$ & 0.007 \\
\hline Maternal parity & $0.44 \pm 0.66$ & $0.57 \pm 0.77$ & $0.65 \pm 0.85$ & 0.758 \\
\hline BMI & $22.05 \pm 3.14$ & $23.01 \pm 3.36$ & $29.5 \pm 6.29$ & $\begin{array}{l}<0.00 \\
1\end{array}$ \\
\hline Smokers & 24 & 25 & 25 & \\
\hline
\end{tabular}

* mean $\pm \mathrm{SD}$, except percentage of smokers

As expected, kidney function test greatly differed between the PE and the other two groups (Table III.). All the observed parameters were increased in the PE group with the statistical difference of $\mathrm{P}<0.001$. CRP levels were similar in all three groups with no significant differences. The normal pregnancies groups had creatinine, uric acid and cystatin levels within the normal range.

The values of plasma MDA, ascorbic acid, SOD and GSH-Px activity are given in Table IV.

In the PE group a significantly higher levels of MDA were found and a greater activity of the GSH-Px enzyme. Also, in the same group we found lower levels of ascorbic acid and decreased activity of SOD. Normal pregnancy groups had similar values of all the observed markers.

Looking into different correlations between the observed parameters in the PE group we found a significant negative correlation between age and GSH-Px activity $(r=-0.646, p=$ 0.022 ), systolic blood pressure and GSH-Px ( $r=-0.372, p=$ 0.043), as well as a positive correlation between the ascorbic acid levels and the SOD activity $(r=-0.369, p=0.045)$. No correlations were found the normal pregnancy groups.

TABLE III: MATERNAL LEVELS OF CREATININE, URIC ACID AND CYSTATINE

\begin{tabular}{lllll}
\hline \hline & $\begin{array}{l}\text { Normal } \\
\text { pregnancy } \\
\text { using } \\
\text { supplement } \\
(\mathrm{n}=34)\end{array}$ & $\begin{array}{l}\text { Normal } \\
\text { pregnancy } \\
\text { no } \\
\text { supplement } \\
(\mathrm{n}=30)\end{array}$ & $\begin{array}{l}\text { PE using } \\
\text { supplement } \\
(\mathrm{n}=30)\end{array}$ & $P$ value \\
& $64.4 \pm 9.88^{*}$ & $57.9 \pm 6.36$ & $69.5 \pm 9.76$ & $<0.001$ \\
\hline $\begin{array}{l}\text { Creatinine } \\
(\mu \mathrm{mol} / \mathrm{L})\end{array}$ & $214 \pm 59.5$ & $223 \pm 40.2$ & $315 \pm 79.3$ & $<0.001$ \\
$\begin{array}{l}\text { Uric acid } \\
(\mu \mathrm{mol} / \mathrm{L})\end{array}$ & $1.09 \pm 0.24$ & $1.06 \pm 0.17$ & $1.44 \pm 0.29$ & $<0.001$ \\
$\begin{array}{l}\text { Cystatine } \\
(\mathrm{mg} / \mathrm{L})\end{array}$ & & & & \\
\hline \hline mean \pm SD & & & & \\
\hline
\end{tabular}

TABLE IV: MATERNAL PlasMA LEVELS OF OXIDATIVE STRESS MARKERS

\begin{tabular}{lllll}
\hline \hline & $\begin{array}{l}\text { Normal } \\
\text { pregnancy } \\
\text { using } \\
\text { supplement } \\
(\mathrm{n}=34)\end{array}$ & $\begin{array}{l}\text { Normal } \\
\text { pregnancy } \\
\text { no } \\
\text { supplement } \\
(\mathrm{n}=30)\end{array}$ & $\begin{array}{l}\text { PE using } \\
\text { supplement } \\
(\mathrm{n}=30)\end{array}$ & $P$ value \\
& $2.77 \pm 0.65 *$ & $2.79 \pm 0.81$ & $2.99 \pm 0.81$ & $<0.05$ \\
\hline $\begin{array}{l}\text { MDA } \\
(\mathrm{pmol} / \mathrm{mg})\end{array}$ & $10.4 \pm 2.49$ & $9.29 \pm 2.38$ & $6.16 \pm 1.66$ & $<0.001$ \\
$\begin{array}{l}\text { Ascorbic acid } \\
(\mathrm{mg} / \mathrm{L})\end{array}$ & $23.7 \pm 14.9$ & $29.9 \pm 22.0$ & $13.0 \pm 11.4$ & $<0.001$ \\
$\begin{array}{l}\text { SOD }(\%) \\
\text { GSH-Px }(\mathrm{U} / \mathrm{L})\end{array}$ & $774 \pm 241$ & $848 \pm 171$ & $1200 \pm 500$ & $<0.05$ \\
\hline \hline * mean \pm SD & & & &
\end{tabular}

\section{DISCUSSION}

Preeclampsia is considered a disorder strongly related to oxidative stress [1], [2], [6], [8], [11]-[13], [16]-[18]. But even in normal pregnancy there is evidence of oxidative stress. Pregnancy was associated with decreased total antioxidant capacity, lower serum levels of individual vitamins and increased levels of lipid hydroperoxides [3], [21]. These biochemical changes may be relevant for the long-term cardiovascular health of women, especially those of high parity or those who are at high risk for cardiovascular disease (e.g. women with diabetes).

Increased levels of ROS and decreased levels of antioxidants found both in normal pregnancy and in the PE are pathophysiological basis for vitamin supplementation 
according to some authors. Supplementation with vitamins has been suggested to decrease infant morbidity and mortality [22]. Even recent European studies have found that there was a positive relationship between total iron intake, from food and supplements, as well as beta-carotene, retinol, vitamins D and $\mathrm{B}_{12}$, pantothenic acid, biotin and magnesium intakes during pregnancy and birth weight [23]-[25]. Multivitamin-mineral supplementation is often recommended to pregnant women in our region although a study on nutritional status in pregnant women has never been done before. In our study we found that in the uncomplicated pregnancy groups multivitamin-mineral supplementation did not influence the levels of ascorbic acid, lipid peroxidation product MDA and the activities of the antioxidant enzymes GSH-Px and SOD. Our findings are in agreement with other larger studies which showed no benefits from vitamin supplementation in pregnancy. There have been several studies, in developed country settings, where no correlation were found between multivitamin-mineral supplement and size at birth, but rather an association with preterm birth if taken daily in the third trimester [26]. Two Cochrane database reviews showed no benefits of vitamin $\mathrm{C}$ and vitamin $\mathrm{E}$ and supplementation in pregnancy to reduce fetal morbidity and mortality and the risk of preeclampsia [27], [28]. The latest Cochrane database review on vitamin supplementation for preventing miscarriage concluded that taking any vitamin supplements prior to pregnancy or in early pregnancy does not prevent women experiencing miscarriage or stillbirth. On the other hand they admit that there is insufficient evidence to examine the effects of different combinations of vitamins on miscarriage, stillbirth or other maternal and infant outcomes [29]. In our study levels of vitamin $C$ and markers of oxidative stress were similar in the two normal pregnancy groups which may be a consequence of a healthy diet in the not treated arm, but also a lack of beneficial effects of the supplement in question. Therefore, it was hypothesized that supplementation of women at risk for PE with antioxidants might prevent the disorder or blunt its severity. Unfortunately, and following a promising preliminary report [30] the results of three double blinded randomized controlled trials failed to corroborate the earlier observation [31], [32]. It should be noted, however, that two of these trials were performed in well-nourished populations, but even in communities at risk of poor nutritional status in developing countries there was no observed benefit in preventing PE [33]. The results of the observed parameters in the PE group have been markedly different to the other two observed groups. The results are not surprising and are in complete agreement with previous studies. The lack of our study is not having a PE group that didn't take supplementation but this was a conscious decision due to study's limited time and budget.

One of our interesting findings is an increased BMI in the PE group compared to the other two groups. Obesity is an independent risk factor for PE even in the early pregnancy [34]. Increased BMI is also a risk factor for isolated gestational proteinuria during normal term pregnancy [35]. A recent study has suggested a possible pathogenic mechanism of increased leptin levels and activation of pro inflammatory cytokines in PE [36]. In this study serum leptin levels in relation to circulating cytokines, chemokines, adhesion molecules and angiogenic factors in normal pregnancy and preeclampsia. In this study leptin levels correlated with BMI in both non-pregnant, pregnant and women with PE. By activating and sustaining inflammation leptin seems to add to otherwise existing low grade inflammation in pregnancy and in this way predispose women to PE.

Kidney function parameters were increased in the PE arm. Besides standard creatinine and uric acid, levels of cystatin were also determined. Renal dysfunction which occurs in PE is a consequence of haemodynamic changes, glomerular lesions and podocyte damage [37]-[40]. It is necessary to closely monitor renal function so that prompt therapy can be undertaken in order to prevent further renal damage. The most widely used markers of renal function in women with PE are serum concentrations of creatinine and uric acid. Creatinine alone has significant shortages as marker of glomerular filtration rate (GFR) because its serum levels can be influenced by numerous non-renal factors such as muscle mass, age and diet. In our study, although the mean creatinine level in PE group was significantly higher in comparison with the two groups with normal pregnancy $(\mathrm{p}<0.0001)$, creatinine serum level was above the reference range in only $25 \%$ of patients with PE. Hyperuricemia in PE is mostly result of decreased GFR and increased tubular re-absorption, but it may occur also due to increased placental production of uric acid (due to increased breakdown of purines in placenta), acidosis, higher activity of xanthine oxidase/dehydrogenase, thus being not only a marker of pathological state and renal dysfunction but also having a role in PE pathogenesis [41]. In our study serum uric acid was above reference range for control group in $37.5 \%$ of PE patients, with significant differences between mean values in three groups $(p<0.0001)$. Serum cystatin C, as a GFR marker, has an advantage because it is not dependent on body composition and its level is stable until the third trimester of pregnancy. In the third trimester its level rises, which can be either a consequence of reduced GFR or increased synthesis of cystatin C [42]. In our study serum cystatin $\mathrm{C}$ levels in PE patients were significantly higher compared to the other two groups $(\mathrm{p}<0.0001)$.

Levels of ascorbic acid, MDA and the activities of two antioxidant enzymes SOD and GSH-Px were taken as markers of oxidative stress. Antioxidant levels in PE are found to be uniformly low in almost all the studies on this subject [43], [44]. Low ascorbic acid and vitamin E levels found in most of the studies were seen as good indicators of the antioxidant/pro oxidant imbalance that characterizes oxidative stress. Low ascorbic acid levels were also a logical basis for supplementation with vitamin $\mathrm{C}$, but as we have shown earlier there is still no clear evidence for that [27]. In our study, ascorbic acid levels were significantly lower even in the PE group that did take the supplement compared to the untreated group of normal pregnancies $(\mathrm{p}<0.001)$. Ascorbic acid has a pivotal role in preventing lipid peroxidation. Therefore it is not surprising that we found increased levels of one of the most reliable lipid peroxidation markers - MDA. Our results showed increased MDA levels in the PE group and this finding is in agreement with most of other studies on the oxidative stress in PE. Lipid peroxidation products are not just markers but also very important pathophysiological factors in PE and in other diseases. In PE toxic lipid peroxides 
contribute to the endothelial dysfunction and hypertension [3], [8], [11], [12], [43], [45]. Although increased MDA can be seen in normal pregnancies as placental tissue suffers lipid peroxidation, levels of this biomarker are always higher in preeclamptic pregnancies due to uncontrolled oxidation.

In our study significantly increased activity of GSH-Px enzyme was found in the PE group. Also, we found a significant negative correlation between age and GSH-Px activity, as well as systolic blood preassure and GSH-Px activity. We have not found any significant correlations in the normal pregnancy group. These findings were in accordance with the results of Mistry et al. [17] who suggested that the decreased GSHP-x activity in PE is associated with the increased generation of lipid peroxides which leads to endothelial dysfunction and hypertension of PE. Selenium

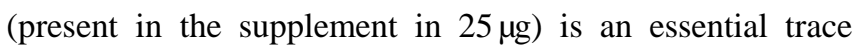
element, involved in the etiology of several diseases [46]. At normal concentrations, selenium may have a protective effect against several diseases. However, this protection is lost at low concentrations and selenium is highly toxic at high concentrations. The GSH-Px activity was suggested to be in direct correlation with selenium levels [47], [48]. Glutathione peroxidase levels in PE were investigated recently by Roland-Zejly et al. [49]. They suggested that the reported decrease in GSH-Px activity and increased oxidative stress in PE placental villi may be attributed in part to GSH-Px 4 isoenzyme, which was in accordance with our results. However, there are few reports suggesting that GSHP-x activity is lowered in PE [50], [51] which confirms the need for further investigations of the topic.

Decreased activity of SOD is one of the hallmarks of PE [11], [12], [14]-[16], [52], [53]. This enzyme is considered one of the most important antioxidant defense mechanisms and its lower activity was used for screening for low antioxidant status and was even predictive of PEE development [54]. So our result in the PE group is in concordance with previous researches and is a no surprise. The fact that the subjects received a multivitamin mineral supplementation did not change the expected statistical difference between the PE and the normal pregnancy group. The activity of this enzyme was often used as a marker of antioxidant supplementation effect and our study there seems to be little or no effect of the multivitamin mineral supplementation on the antioxidant status in all three arms.

\section{CONCLUSION}

This study was the first study on the effect on multivitamin mineral supplementation in pregnancy on the population in Vojvodina region. Observing a complex set of parameters in three arms, we found no clear beneficial effect of this kind of supplementation. The reason for this might be a generally healthy eating habits and good prenatal care in our region, but also further research is needed to include nonsupplemented $\mathrm{PE}$ group and have a full insight into the importance of antioxidant supplementation in pregnancy.

\section{REFERENCES}

[1] C. Rusterholz, S. Hahn, and W. Holzgreve, "Role of placentally produced inflammatory and regulatory cytokines in pregnancy and the etiology of preeclampsia," Semin. Immunopathol., vol. 29, pp. 151-162, 2007.

[2] J. R. Challis, C. J. Lockwood, L. Myatt, J. E. Norman, J. F. Strauss, and F. Petraglia, "Inflamation and pregnancy," Reproductive Science, vol. 16, no 2, pp. 206-215, 2009.

[3] V. Toescu, S. L. Nuttall, U. Martin, M. J. Kendall, and F. Dunne "Oxidative stress and normal pregnancy," Clin. Endocrin., vol. 57, no. 5, pp. 609-613, 2002.

[4] J. Dotsch, N. Hogen, Z. Nyul, J. Hanze, I. Knerr, and M. Kirschbaum, "Increase of endothelial nitric oxide synthase and endothelin-1 mRNA expression in human placenta during gestation," Eur. J. Obstet. Gynecol. Reprod. Biol., vol. 97, pp. 163-167, 2001

[5] L. Myatt and X. Cui, "Oxidative stress in the placenta," Histochem. Cell Biol., vol. 122, pp. 369-382, 2004.

[6] B. Sibai, G. Dekker, and M. Kupferminc, "Pre-eclampsia," Lancet, vol. 365, pp. 785-799, 2005.

[7] C. W. Redman, and I. L. Sargent, "Latest advances in understanding preeclampsia," Science, vol. 308, pp. 1592-1594, 2005.

[8] Z. Serdar, E. Gur, M. Colakoethullary, O. Develioethlu, and E. Sarandol, "Lipid and protein oxidation and antioxidant function in women with mild and severe preeclampsia," Arch. Gynecol. Obstet., vol. 68, pp. 19-25, 2003.

[9] N. Soleymanlou, I. Jurisica, O. Nevo, F. Ietta, X. Zhang, S. Zamudio, M. Post, and I. Caniggia, "Molecular evidence of placental hypoxia in preeclampsia," J. Clin. Endocrinol. Metab., vol. 90, pp. 4299-4308, 2005.

[10] D. Del Rio, A. Stewart, and N. A. Pellegrini, "A review of recent studies on malondialdehyde as toxic molecule and biological marker of oxidative stress," Nutr. Metab. Cardiovasc. Dis., vol. 15, pp. 316-328, 2005.

[11] S. Aydin, A. Benian, R. Madazli, S. Uludag, H. Uzun, and S. Kaya, "Plasma malondialdehyde, superoxide dismutase, sE-selectin, fibronectin, endothelin-1 and nitric oxide levels in women with preeclampsia," Eur. J. Obstet. Gynecol. Reprod. Biol., vol. 113, pp. 21-25, 2004

[12] P. Panburana, W. Phuapradit, and O. Puchaiwatananon, "Antioxidants, nutrients and lipid peroxide levels in Thai preeclamptic pregnant women," J. Obstet. Gynaecol. Res., vol. 26, pp. 377-381, 2000.

[13] E. Jauniaux, A. L. Watson, J. Hempstock, Y. P. Bao, J. N. Skepper, and G. J. Burton, "Onset of maternal arterial blood flow and placental oxidative stress. A possible factor in human early pregnancy failure," Am. J. Pathol., vol. 157, pp. 2111-2122, 2000.

[14] Y. Wang and S. W. Walsh, "Increased superoxide generation is associated with decreased superoxide dismutase activity and mRNA expression in placental trophoblast cells in pre-eclampsia," Placenta, vol. 22, pp. 206-212, 2001.

[15] F. Bernardi, L. Constantino, R. Machado, F. Petronilho, and F. Dal-Pizzol, "Plasma nitric oxide, endothelin-1, arginase and superoxide dismutase in pre-eclamptic women," J. Obstet. Gynaecol. Res., vol. 34, no. 6, pp. 957-963, 2008.

[16] E. Bulgan Kilicdag, G. Ay, A. Celik, B. Ustundag, I. Ozercan, and M. Simsek, "Oxidant-antioxidant system changes relative to placental-umbilical pathology in patients with preeclampsia," Hypertens. Pregnancy, vol. 24, pp. 147-157, 2005.

[17] H. D. Mistry, V. Wilson, M. M. Ramsay, M. E. Symonds, and F. Broughton Pipkin, "Reduced selenium concentrations and glutathione peroxidase activity in preeclamptic pregnancies," Hypertension, vol. 52, no. 5, pp. 881-888, 2008

[18] S. Gupta, N. Aziz, L. Sekhon, R. Agarwal, G. Mansour, J. Li, and A Agarwal, "Lipid peroxidation and antioxidant status in preeclampsia: a systematic review," Obstet. Gynaecol. Surv., vol. 64, no. 11, pp. 750-759, 2009.

[19] D. E. Paglia and W. N. Valentine, "Studies on the quantitative and qualitative characterization of erythrocyte glutathione peroxidase," Lab. Clin. Med., vol. 70, pp. 158-169, 1967.

[20] C. A. Burtis and E. R. Ashwood, Tietz textbook of clinical chemistry, 4th ed. Philadelphia: Saunders, pp1107, 2006.

[21] M. Suhail, S. Patil, S. Khan, and S. Siddiqui, “Antioxidant Vitamins and lipoperoxidation in non-pregnant, pregnant, and gestational diabetic women: erythrocytes osmotic fragility profiles," J. Clin. Med. Res., vol. 2, no. 6, pp. 266-273, 2011. 
[22] T. O. Scholl, M. L. Hediger, A. Bendich, J. I. Schall, W. K. Smith, and P. M. Krueger, "Use of multivitamin/mineral prenatal supplements: influence on the outcome of pregnancy," Am. J. Epidemiol., vol.146, pp. 134-141, 1997.

[23] N. A. Alwan, D. C. Greenwood, N. A. Simpson, H. J. McArdle, K. M. Godfrey, and J. E. Cade, "Dietary iron intake during early pregnancy and birth outcomes in a cohort of British women," Hum. Reprod., vol. 26, no. 4, pp. 911-919, 2011

[24] P. E. Watson and B. W. McDonald, "The association of maternal diet and dietary supplement intake in pregnant New Zealand women with infant birthweight," Eur. J. Clin. Nutr., vol. 64, no. 2, pp. 184-193, 2010.

[25] S. Finer, K. S. Khan, G. A. Hitman, C. Griffiths, A. Martineau, and C. Meads, "Inadequate vitamin D status in pregnancy: evidence for supplementation," Acta. Obstet. Gynecol. Scand., doi 10.1111/j.1600-0412.2011.01305.x, 2011.

[26] N. A. Alwan, D. C. Greenwood, N. A. Simpson, H. J. McArdle, and J. E. Cade JE, "The relationship between dietary supplement use in late pregnancy and birth outcomes: a cohort study in British women," BJOG., vol. 117, no. 7, pp. 821-829, 2010.

[27] A. Rumbold and C. A. Crowther, "Vitamin C supplementation in pregnancy (review)," The Cochrane Library, issue 7, 2010.

[28] A. Rumbold and C. A. Crowther, "Vitamin E supplementation in pregnancy (review)," The Cochrane Library, issue 7, 2010.

[29] A. Rumbold, P. Middleton, N. Pan, and C. A. Crowther, "Vitamin supplementation for preventing miscarriage (Review)," The Cochrane Library, Issue 1, 2011.

[30] L. Chappell, P. Seed, A. Briley, J. Kelly, R. Lee, and B. J. Hunt., "Effect of antioxidants on the occurrence of pre-eclampsia in women a increased risk: a randomised trial," Lancet, vol. 354, pp. 810-816, 1999.

[31] L. Poston, A. Briley, P. Seed, F. Kelly, and A. Shennan, "The Vitamins in pre-eclampsia (VIP) trial consortium. vitamin $\mathrm{C}$ and vitamin $\mathrm{E}$ in pregnant women at risk for pre-eclampsia (VIP trial): randomised placebo-controlled trial," Lancet, vol. 367, pp. 1145-1154, 2006.

[32] A. Rumbold, C. Crowther, R. Haslam, G. Ekker, and J. Robinson, "Vitamins $\mathrm{C}$ and $\mathrm{E}$ and the risks of preeclampsia and perinatal complications," N. Engl. J. Med., vol. 354, pp. 1796-1806, 2006.

[33] J. Villar, M. Purwar, M. Merialdi, N. Zavaleta, N. Thi Nhu Ngoc, J. Anthony, A. De Greeff, L. Poston, and A. Shennan, "World health organisation multicentre randomised trial of supplementation with vitamins $\mathrm{C}$ and $\mathrm{E}$ among pregnant women at high risk for pre-eclampsia in populations of low nutritional status from developing countries," BJOG., vol. 116, no. 6, pp. 780-788, May 2009.

[34] A. Syngelaki, F. E. Bredaki, E. Vaikousi, N. Maiz, and K. H. Nicolaides, "Body mass index at 11-13 weeks' gestation and pregnancy complications," Fetal Diagn. Ther. PMID: 22067258, 2011.

[35] C. Macdonald-Wallis, D. A. Lawlor, J. Heron, A. Fraser, and S. M. Nelson, "Tilling Relationships of risk factors for pre-eclampsia with patterns of occurrence of isolated gestational proteinuria during normal term pregnancy," PLoS One., vol. 6, no. 7, e22115, 2011.

[36] A. Molvarec, A. Szarka, S. Walentin, G. Beko, I. Karádi, Z. Prohászka, and J. Jr. Rigó, "Serum leptin levels in relation to circulating cytokines, chemokines, adhesion molecules and angiogenic factors in normal pregnancy and preeclampsia," Reprod. Biol. Endocrinol., vol. 9, pp. $124-129,2011$.

[37] N. Franceschini, C. Qiu, D. Barrow, and M. Williams, "Cystatin C and preeclampsia: a case control study," Ren. Fail., vol. 30, pp. 89-95, 2008.

[38] R. A. Lafayette, M. Druzin, R. Sibley, G. Derby, T. Malik, and P. Huie, "Nature of glomerular disfunction in pre-eclampsia," Kidney Int., vol. 54, pp. 1240-1249, 1998.

[39] V. D. Garovic, S. J. Wagner, S. T. Turner, D. W. Rosenthal, W. J. Watson, and F. Brost, "Urinary podocyte excretion as a marker for preeclampsia," Am. J. Obstet. Gynecol., vol. 196, pp. 321-327, 2007.

[40] A. Novakov Mikic, V. Cabarkapa, A. Nikolic, D. Maric, S. Brkic, G. Mitic, and M. Ristic, "Cystatin C in pre-eclampsia," J. Matern. Fetal Neonatal Med., In Press, 2012.

[41] C. Koopmans, M. Van Pampus, H. Groe, J. Aarnoudse, P. Van der Berg, and B. Mol, "Accuracy of serum uric acid as a predictive test for maternal complications in pre-eclampsia: Bivariate meta-analysis and decision analysis," Eur. J. Obstet. Gynecol. Reprod. Biol., vol. 146, pp 8-14, 2009.

[42] A. Akbari, N. Lepage, E. Keely, H. D. Clark, J. Jaffey, and M. MacKinnon, "Cystatin $\mathrm{C}$ and beta trace protein as markers of renal function in pregnancy," Br. J. Obstet. Gynecol., vol. 112, pp.575-578, 2005.
[43] G. Kaur, S. Mishra, A. Sehgal, and R. Prasad, "Alterations in lipid peroxidation and antioxidant status in pregnancy with preeclampsia," Mol. Cell. Biochem., vol. 313, no. 1-2, pp. 37-44, 2008.

[44] E. Llurba, E. Gratacós, P. Martín-Gallán, L. Cabero, and C. Dominguez, "A comprehensive study of oxidative stress and antioxidant status in preeclampsia and normal pregnancy," Free. Radic. Biol. Med., vol. 37, no. 4, pp. 557-570, 2004.

[45] E. Bulgan Kilicdag, G. Ay, A. Celik, B. Ustundag, I. Ozercan, and M. Simsek, "Oxidant-antioxidant system changes relative to placental-umbilical pathology in patients with preeclampsia, Hypertens. Pregnancy, vol. 24, pp. 147-157, 2005.

[46] E. Noaman, A. M. Zahran, A. M. Kamal, and M. F. Omran, "Vitamin E and selenium administration as a modulator of antioxidant defence system: Biochemical assessment and modification," Biol. Trace Elem. Res., vol. 86, pp. 55-64, 2002

[47] Y. Takata, J. S. Morris, I. B. King, A. R. Kristal, D. W. Lin, and U. Peters, "Correlation between selenium concentrations and glutathione preoxidase activity in serum and human prostate tissue," Prostate, vol. 69 , no. 15 , pp. 1635-1642, 2009.

[48] G. A. Jacobson, C. Narkowicz, Y. C. Tong, and G. M. Peterson, "Plasma glutathione peroxidase by ELISA and relationship to selenium level," Clin. Chim. Acta, vol. 369, no. 1, pp. 100-103, 2006.

[49] L. Roland-Zejly, V. Moisan, I. St-Pierre, and J. F. Bilodeau, "Altered placental glutathione peroxidase mRNA expression in preeclampsia according to the presence or absence of labor," Placenta, vol. 32, no. 2, pp. 161-167, 2011.

[50] Y. Wang and S. W. Walsh, "Antioxidant activities and mRNA expression of superoxide dismutase, catalase, and glutathione peroxidase in normal and preeclamptic placentas," Reproductive Sciences, vol. 3, no. 4, pp. 179-184, 1996.

[51] E. F. Funai, A. MacKenzie, S. S. Kadner, H. Roque, M. J. Lee, and E. Kuczynski, "Glutathione peroxidase levels throughout normal pregnancy and in pre-eclampsia," J. of Maternal-Fetal and Neonatal Medicine, vol. 12, no. 5, pp. 322-326, 2002.

[52] N. Z. Dordević, G. M. Babić, S. D. Marković, B. I. Ognjanović, A. S. Stajn, R. V. Zikić, and Z. S. Saicić, "Oxidative stress and changes in antioxidative defense system in erythrocytes of preeclampsia in women," Reprod. Toxicol., vol. 25, no. 2, pp. 213-218, 2008.

[53] K. V. Mahadik, and S. A. Sina, "Study of serum levels of superoxide dismutase in preeclampsia and eclampsia: role of the test as a predictive tool," J. Obstet. Gynaecol. Res., vol. 29, no. 4, pp. 262-267, 2003.

[54] D. Rumiris, Y. Purwosunu, N. Wibowo, A. Farina, and A. Sekizawa, "Lower rate of preeclampsia after antioxidant supplementation in pregnant women with low antioxidant status," Hypertens. Pregnancy, vol. 25 , no. 3, pp. 241-253, 2006.

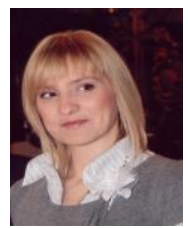

Tatjana N. Ćebović is a member of IAENG, who was born in Novi Sad, Vojvodina, Serbia in 1976. She completed the elementary and high school education in Novi Sad. In 1995 she entered Faculty of Pharmacy in Belgrade and Faculty of Sciences in Novi Sad where she graduated in 1999 as the best student of the generation and earned the master degree in Biochemistry (MSc). In 2000 she started her postgraduate studies which she completed in 2003 and earned the magister degree in Biochemistry. In 2004 she started her doctoral studies at the Faculty of Pharmacy in Belgrade which she completed in 2008 and earned the PhD degree in Pharmaceutical Sciences (Medical Biochemistry).

As a student of the second year she started her scientific work when she won several prizes. After graduation she joined the research group at the Faculty af Sciences in Novi Sad as a Research Assistant. Today she is employed as a Chief of the Biochemistry Department at the Clinical Centre of Vojvodina and a Chief of the Biochemistry Department at the Faculty of Medicine in Novi Sad where she holds the Assistant Professor position. She published a number of scientific papers, gave a number of lectures at international conferences, published one book and two monographies.

Ass. Prof. Ćebović is a member of Phytochemical Society of Europe, GA, FEBS and several others. She also won several international prizes for Young Researchers.

Daniela T. Marić was born in Novi Sad, Vojvodina, Serbia in 1977. She completed the elementary and high school education in Novi Sad. In 1996 she entered Medical school University of Novi Sad, where she graduated in 2003. She earned magister degree in Physiology in 2008, and PhD degree in Clinical Medicine in 2011 
From 2006. she is employed as a Clinical phyisician at Infectious diseases clinic, Clinical Centre of Vojvodina and $\mathrm{s}$ an assistant on the Cathedra for infectious diseases, Medical school, University of Novi Sad.

She published a number of scientific papers in international journals. She was a coauthor in two books.

Ass. dr Marić is a member of Serbian physicians society. He interests include mainly oxidative stress in chronic viral infections.

Aleksandra Nikolić was born in Novi Sad, Serbia on 14th October 1964. She received her Ph.D. in Biochemistry from Faculty of Sciences, University of Novi Sad, Serbia. Since 1991 she worked as a biochemist in Biochemical Laboratory Department on Clinic of Gynecology and Obstetrics, Clinical Center Vojvodina. From 1997-2012 she is the head of Biochemical laboratory Department. From 2003-2011 she worked as assistant on Subject of Pharmacognosy, Faculty of Pharmacy in Novi Sad, Serba; from 2011 she became Assistant Professor on two different subjects-Pharmacognosy and Social Pharmacy. During 1996 she got British Council fellowship at St Thomas and King's College Hospital, London. The fields of her research interests are oxidative stress and prenatal biochemical screening as well as the phytotherapy. She had 51 scientific work, statements and abstracts in domestic and foreign magazines published (6 on sci list).

Dr Nikolić is active member of The Society of Medical Biochemistry of Serbia (DMBS) and Biochemical Chamber of Serbia.

Aleksandra Novakov Mikić was born in Novi Sad, Serbia in 1967. After she received a BA in general medicine at University of Novi Sad in 1990 she joined Department of Gynaecology and Obstetrics in Novi Sad as a scientific research assistant. She obtained MSc in 1995, Ph.D in 1999. in the field of Obstetrics and Gynaecology at University of Novi Sad and also earned subspecialist diploma in Perinatology in 2010. She completed her Ob/Gyn residency at Department of Gynaecology and Obstetrics in Novi Sad and became consultant in 1996. She had several international trainings in Florida (USA), Sevilla (Spain), Budapsest (Hungary) and was awarded subspecialist diploma in Fetal Medicine from Harris Birthright Research Centre for Fetal Medicine, King's College Hospital, London (UK) in 1998. She is a full time professor of Obstetrics and Gynaecology at University of Novi Sad, Medical
School and the head of the Department of Fetal Medicine, Prenatal Diagnostic and Therapy, at the Department for Obstetrics and Gynaecology, Clinical Centre of Vojvodina, Novi Sad, Serbia. She was Consultant of European Agency for Reconstruction (EAR) for education and training programme for gynaecologist in primary and secondary health care in ultrasound and screening in first trimester. In 2007 she was the assistant of the general Manager of the Clinical Centre of Vojvodina in the field of science and education. She served as General Manager of Department for Gynecology and Obstetrics, Clinical Centre of Vojvodina from 2007 to 2011 and a Member of the City Council of Novi Sad in charge of Health from 2008 to 2011. She was a member of the Committee for strategic development of University of Novi Sad, member of Committee for science of Medical faculty, University of Novi Sad and still is a vice president of the Expert committee for medical sciences of the Senate of University of Novi Sad. She is the author and co-author of more than 200 papers and book chapters and three guidelines for ultrasound and fetal echocardiography.

Professor Novakov Mikić is a member of numerous professional societies and committees: Member of International society of ultrasound in obstetrics and gynaecology (ISUOG), Referee of international journal Ultrasound in Obstetrics and Gynaecology, member of Executive Board of Serbian Association of Ultrasound in Obstetrics and Gynaecology and mentor Transplant team of the Clinical Center of Vojvodina - gynecological team member, member of Continual Medical Education Committee of The Society of physicians of Vojvodina of The Medical Society od Serbia, Vice president of Presidency of Gyneecology and Obstetrics section of The Serbian Medical Society, President of Professional Council for the enhancement and protection of the environment of the Provincial Secretariat for Science and Technological Development AP Vojvodina.

In 2001 her presentation,,Transvaginal ultrasonography of the cervix and vaginal fetal fibronectin in prediction of outcome of induction was awarded as the best scientific work by Fetal Medicine Foundation in London. She was awarded the medal "Dr Nikola Hadži Nikolic", by The Gynaecology Obstetrics section of The Medical Society of Serbia, Belgrade in 2006 as well as Award of the Ministry of Health of the Republic of Serbia and the European Agency for Reconstruction for the improvement of maternal health, Belgrade in 2007. 